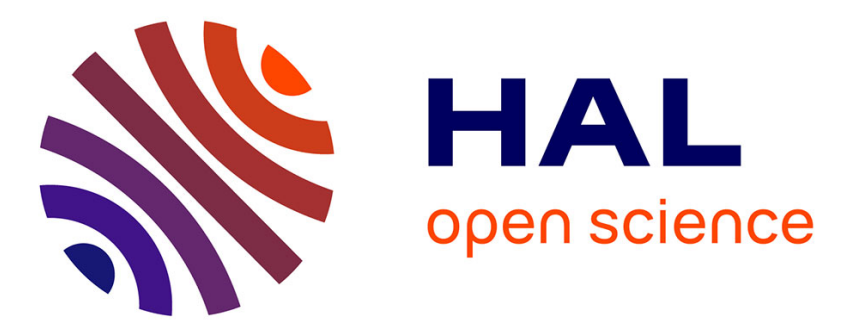

\title{
Sustainable development in post-devolution UK and Ireland
}

\author{
Graham Haughton, David Counsell, Geoff Vigar
}

\section{To cite this version:}

Graham Haughton, David Counsell, Geoff Vigar. Sustainable development in post-devolution UK and Ireland. Regional Studies, 2008, 42 (09), pp.1223-1236. 10.1080/00343400802360444 • hal-00514718

\section{HAL Id: hal-00514718 \\ https://hal.science/hal-00514718}

Submitted on 3 Sep 2010

HAL is a multi-disciplinary open access archive for the deposit and dissemination of scientific research documents, whether they are published or not. The documents may come from teaching and research institutions in France or abroad, or from public or private research centers.
L'archive ouverte pluridisciplinaire HAL, est destinée au dépôt et à la diffusion de documents scientifiques de niveau recherche, publiés ou non, émanant des établissements d'enseignement et de recherche français ou étrangers, des laboratoires publics ou privés. 


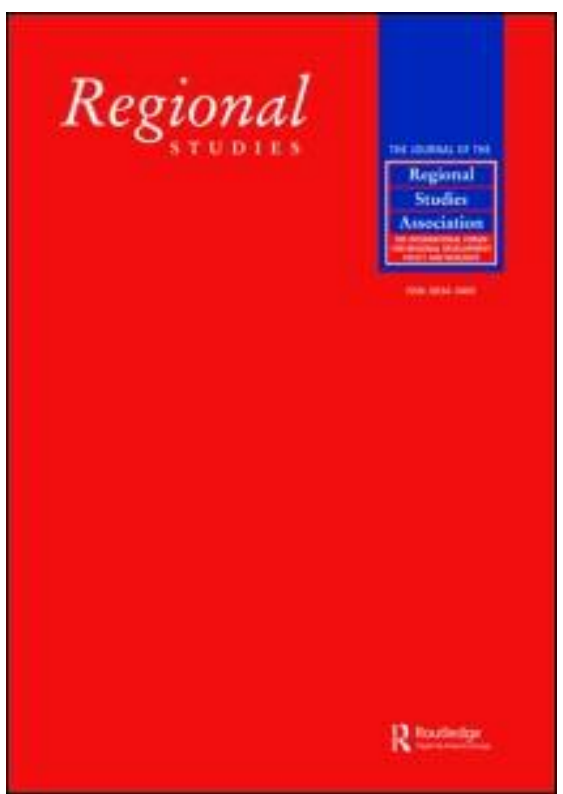

Sustainable development in post-devolution UK and Ireland

\begin{tabular}{|r|l|}
\hline Journal: & Regional Studies \\
\hline Manuscript ID: & CRES-2007-0145.R2 \\
\hline Manuscript Type: & Main Section \\
\hline JEL codes: & $\begin{array}{l}\text { Q01 - Sustainable Development < Q0 - General < Q - Agricultural } \\
\text { and Natural Resource Economics, Q28 - Government Policy < Q2 - } \\
\text { Renewable Resources and Conservation IEnvironmental } \\
\text { Management < Q - Agricultural and Natural Resource Economics, } \\
\text { R5 - Regional Government Analysis < R - Urban, Rural, and } \\
\text { Regional Economics }\end{array}$ \\
\hline Keywords: & $\begin{array}{l}\text { Sustainable development, strategies, sustainable regions, } \\
\text { devolution, policy communities, metagovernance }\end{array}$ \\
\hline \multicolumn{2}{|l}{} \\
\hline
\end{tabular}

\section{(5) ScholarONE \\ Manuscript Central}




\title{
Sustainable development in post-devolution UK and Ireland
}

\author{
Graham Haughton, ${ }^{1}$ Dave Counsell ${ }^{1}$ and Geoff Vigar $^{2}$ \\ First received: June 2007 \\ Accepted: May 2008
}

\begin{abstract}
Strategies for sustainable development have been produced aplenty in recent years, with numbers increasing in the context of devolution. This article examines the way in which they have developed. We examine the role of strategies for sustainable development as a metagovernance and policy integration device. The limited evidence of diversity in approaches to sustainable development post-devolution is a key finding.
\end{abstract}

Acknowledgements: This work was funded under ESRC grant number RES000-23-0756. The diagrams are Crown Copyright material reproduced with the permission of HMSO and the Queen's Printer for Scotland, (licence number CO2W002008). We would like to thank our reviewers and the editors for some very helpful comments.

\footnotetext{
Keywords: sustainable development multi-level governance metagovernance policy integration devolution
} 
JEL: Q01, Q28 - Q2 R5

Le développement durable au Royaume-Uni et en Irlande depuis la régionalisation.

Haughton et al.

Au cours des années récentes, de nombreuses stratégies en faveur du développement durable ont été mises au point, dont un nombre croissant dans le domaine de la régionalisation. Cet article cherche à examiner la façon dont elles ont été élaborées. On examine le rôle des stratégies en faveur du développement durable comme système de métagouvernance et d'intégration de politique. Un résultat clé c'est l'absence de preuves d'une diversité de façons d'aborder la question du développement durable depuis la régionalisation.

Développement durable / Gouvernance à plusieurs niveaux / Métagouvernance / Intégration de politique / Régionalisation

Classement JEL: Q01; Q28; Q2; R5

Nachhaltige Entwicklung in Großbritannien und Irland nach der Dezentralisierung

Graham Haughton, Dave Counsell and Geoff Vigar

Abstract:

In den letzten Jahren wurden zahlreiche Strategien für nachhaltige

Entwicklung hervorgebracht, wobei die Anzahl im Kontext der

Dezentralisierung noch weiter anstieg. In diesem Beitrag wird untersucht, in welcher Weise sich diese Strategien weiterentwickelt haben. Wir untersuchen die Rolle der Strategien für nachhaltige Entwicklung als Mittel der MetaRegierungsführung und politischen Integration. Eines der wichtigsten Ergebnisse hinsichtlich der Ansätze zur nachhaltigen Entwicklung in der Zeit nach der Dezentralisierung sind die begrenzten Anzeichen von Vielfalt.

Keywords:

Nachhaltige Entwicklung

Regierungsführung auf mehreren Ebenen

Meta-Regierungsführung

Politische Integration

Dezentralisierung

JEL: Q01, Q28 - Q2 R5 
Desarrollo sostenible tras la transferencia de competencias en el RU e Irlanda

Graham Haughton, Dave Counsell and Geoff Vigar

Abstract:

Se han creado abundantes estrategias para el desarrollo sostenible en los últimos años con un número creciente en el contexto de la transferencia de competencias. En este artículo examinamos el modo en que se han desarrollado estas estrategias. Examinamos el papel de las estrategias para el desarrollo sostenible como dispositivo de metagobierno y para la integración de políticas. Un resultado clave fue la evidencia limitada de la diversidad en enfoques para el desarrollo sostenible tras la transferencia de competencias.

Keywords:

Desarrollo sostenible

Gobierno multinivel

Metagobierno

Integración política

Transferencia de competencias

JEL: Q01, Q28 - Q2 R5

${ }^{1}=$ Department of Geography

University of Hull

Hull HU6 7RX

g.f.haughton@hull.ac.uk

${ }^{2}=$ Global Urban Research Unit, School of Architecture, Planning and

Landscape, Newcastle University, Newcastle NE1 7RU.

counsell@supanet.com, G.I.Vigar@ newcastle.ac.uk 


\section{Sustainable regional development in post-devolution}

\section{UK and Ireland}

\section{Devolution, sustainable development and new systems of territorial management}

Since the early-1990s there have been significant moves towards political and administrative devolution across the British Isles. Focusing on the period of intensive devolution since 1997, this paper examines whether devolution is leading to innovation and divergence in the recently published strategies for sustainable development in the UK and Ireland. Our expectation was that some divergence in practices in the new territorial systems should be evident, especially as the newly created devolved administrations working from the 'bottom up' would develop policies better aligned with the specific needs and aspirations of their territories, rather than those of central government (Morgan 2001, 2002). We also expected the different levels of devolved responsibility to be an influence, given that the varying powers and resources accompanying the creation of the Scottish Parliament, Welsh Assembly, Northern Ireland Assembly, and the Greater London Authority would influence their ability to deliver sustainable development. Whilst political devolution to the English regions appears to have stalled, devolved administrative responsibilities have been established at regional level, including responsibility for the production of regional sustainable development frameworks and regional spatial strategies. The Republic of Ireland is 
interesting because of its growing links to Northern Ireland, plus it has been active in promoting both sustainable development and limited forms of regional devolution.

Policy in the devolved territories might well be expected to show varying levels of divergence from national policy, not least given the path dependencies arising out of previous devolutionary initiatives (Keating 2005) and the asymmetrical nature of contemporary devolution (Cooke and Clifton 2005). Taking this further, Cooke and Clifton (2005) argue that it is already possible to see 'varieties of devolution' across the devolved UK territories in relation to economic governance. This fits well with the view that greater distinctiveness might be expected to emerge in those policy arenas where greatest powers and resources are devolved, such as economic development and transport (MacKinnon and Vigar forthcoming). By contrast, 'sustainable development' is a policy area where devolved responsibility is not fully reflected in devolved powers and resources. For example two key policy areas of relevance to sustainable development, energy and airports, have been 'retained' by the UK Government.

The 1992 Rio Earth Summit called on governments to take the lead in producing national and local strategies for sustainable development, leading to considerable policy work at both national and local level and with it a considerable academic literature (e.g. Lafferty and Eckerberg 1998, Low et al. 2000). Reflecting the growing strengthening of regional institutions in many countries, recent years have seen the rise of regional strategies for 
sustainable development (Benneworth, Roberts and Convoy 2002, Lafferty and Narodoslawsky 2003). This article seeks to conceptualise the later rounds of sustainable development strategy making as a form of metagovernance, linked into a wider process of rescaling governance arrangements. Arguing that these strategies are important devices for policy integration, which bring together new policy communities to negotiate strategy statements, sustainable development strategies are seen as one aspect of negotiating around the contradictory tendencies inherent in the current round of state restructuring, not least the desire to enhance devolution whilst retaining some sense of central coordination.

\section{Policy integration, policy communities and metagovernance}

In the context of the wider rescaling of the state, the emerging institutionbuilding and strategy work of devolved nations and regions represents the 'filling in' of the sub-national systems of governance, a process which is working out variably in different places (Goodwin et al. 2005) The process of developing strategies at newly empowered scales of governance allows new communities of practice to emerge, as stakeholders seek to shape not only the strategy itself but subsequent policies for implementation. The breadth of these policy communities has tended to increase, not only as governments come under pressure for greater transparency and public engagement, but also as a result of the political impetus to improve the integration of policy across scales and across policy sectors. We want to argue here that for wide- 
reaching policy areas such as sustainable development, the performance of agreeing a strategy itself represents an important metagovernance function.

Metagovernance refers to the ways in which the 'rules of the game' are established for devolved systems of governance, that is the steering of governance (Jessop 2000, 2004). If governance is about selectively engaging new actors and voices in the policy process, metagovernance is about finding a variety of ways for ensuring that through internal processes of debate and external rule setting, the new governance mechanisms work within a series of visible and less visible constraints. Requiring policy coordination and integration across actors and between different sectoral strategies not only reduces conflict and duplication, it also brings with it a certain disciplinary power over maverick elements in the new policy communities. One of the roles of metagovernance is to provide coherence across the increasingly fragmentary landscapes of governance, as new sub-national governance bodies are created at a range of different scales and with different mixes of policy mandates. In Jessop's (2000) strategic relational approach, state structures, including governance structures, are not necessarily unified or functional for capital, pushing through a particular agenda. He argues instead that each situation must be explored historically-empirically, examining the structural contradictions and strategic dilemmas involved. Metagovernance then is not simply the functional imposition of a set of rules by some higher authority. Rather it refers to the processes by which different social forces come together to develop and pursue particular strategic approaches, which 
may be contested at and across different spatial scales and by different sets of actors (Jessop 2003, 2004).

This latter point can usefully be explored through thinking of how policy communities form and subsequently function, particularly during periods of organisational creation and turbulence. Individuals within policy domains tend to cohere into networks with varying degrees of openness and cultures of practice. Established networks can become very conservative with an established set of rules and resources that govern what constitutes legitimate knowledge and action (Marsh and Rhodes 1992; Coleman et al. 1997, Smith 1993). By contrast, when governance systems are opened up, or where new policy domains emerge, things tend to be relatively fluid with new networks and communities of practice being formed, as in the case of developing sustainable development strategies in newly devolved territories.

This creates the opportunity for existing policy communities to adapt to the new circumstances, or for new policy communities to form. In either case their rationale essentially stems from being given the metagovernance task of producing a sustainable development strategy, encompassing a mandate to integrate sectorally across policy domains, bring together diverse stakeholder groups, and join-up policy vertically across scales of governance. The polity from which such strategies emerge is thus made up of various communities which are variously interlocking and shifting in composition and place within the broader multi-scalar polity. These may be ephemeral and dissolve following strategy preparation, or may be derived from an existing community, and may in any case endure for the purposes of implementation. 
Policy integration can be justified in terms of avoiding risks of duplication, governance failure and avoiding counter-productive policy directions (Allmendinger and Haughton 2007, Vigar et al 2000). Its pursuit is of itself complex, requiring a range of policy devices for ensuring different strategies are joined-up. Effective policy integration generally requires coherent policy communities to come together to agree both on individual sectoral strategies, and on how different sectoral strategies 'join up'. The politics of integration then requires the brokering of agreement around particular approaches that need to be 'bought into' by all the dominant players, with those outside the process risking alienation and disengagement. This is particularly evident in the case of work to produce sustainable development and spatial strategies, which are inherently multi-sectoral in nature, requiring considerable investment of time in discussion and negotiation. In order to police these agreements, systems of audit, appraisal, scrutiny, monitoring, and evaluation are now common-place, seeking to ensure all those who agreed to a strategy, and those who want to use it to pursue their own strategic interests, follow its spirit and its specific policies.

The metagovernance challenge which arises from the devolution impetus is to retain legitimacy for the wider devolution project through not simply allowing but encouraging policy diversity, whilst retaining some level of coherence to the way in which policy in different sectoral domains is pursued. These are some of the structural contradictions and strategic dilemmas that Jessop's work highlights. We might reasonably expect greater distinctiveness 
to emerge where the devolution settlement is most generous. This, though, is mediated through the very practical realities of whether the new territorial politics align with those of the central government of the day. Where different political parties have control, greater distinctiveness ought to ensue. With a national Labour government in power, the first two elections after devolution returned Labour administrations in Scotland and Wales, a situation which radically changed in 2007 when the Scottish National Party took control in Scotland and a Labour-Plaid Cymru coalition was established in Wales. In the Irish regions and most English regions, there is no elected tier of government, reducing the legitimacy, and the capacity, of regional authorities to challenge national authorities.

In this context, metagovernance works through an interplay of previous modes of hierarchical 'command and control' decision-making, with more networked forms of governance, especially at sub-national levels (Whitehead 2003). Seen as a reflexive set of experiments in devolution and filling-in of the state, metagovernance provides a useful way of understanding how certain policies for sustainability might still be being transferred largely unchanged from the centre to devolved spaces, whilst elsewhere greater local distinctiveness emerges.

\section{Sustainable development policy as an integrative device}

Recent official definitions of sustainable development have tended to promote an integrative approach, where economic, social and environmental issues are meant to be accorded equal status. This integrative approach echoes the 
wider political and administrative impetus for moving away from 'silo thinking' towards more joined-up government (Cabinet Office 1999a, 1999b; Performance and Innovation Unit 2000). Such a move was also a justification for devolution itself (Cabinet Office 1999a). There are other political imperatives at work too, since the integrated definition of sustainable development helps ensure that the moral high ground of 'sustainability' cannot be captured solely by 'environmental' interests. Moreover, promoting 'stakeholder' agreement around an agreed understanding of sustainable development is one way of reigning in 'maverick' elements in a policy community, so that the strategy making process does not end up in major dispute and disarray (Vigar et al. 2000). Alternatively, following Gunder (2006), it may be that the integrated definition of sustainable development, with its insertion of an economic rationality into the heart of sustainability, is one of the ways in which sustainable development is being captured by and deployed within neoliberalist discourse, reducing its capacity to engender radical change.

The integrative thrust of recent definitional work on sustainable development is reinforced though political pressure to ensure that different sectoral strategies are mutually supportive and that consultation processes for each strategy are broadened out to cover all actors with a potential interest. The result is an increasingly complex set of inter-penetrating relationships, as those responsible for producing specific strategies seek to ensure that they show some level of recognition of other strategies. Whilst there is a danger of such governance arrangements leading to a 'lowest common denominator' 
blandness around minimalist agreements, devolution demands some level of distinctiveness. Some of this may be genuine, some largely presentational.

Sustainable development strategies then are interesting in terms of their metagovernance role as integrative devices both in their own right, and in terms of how other governmental strategies are expected to incorporate the resulting understanding of sustainable development into their own work. We explore below the recent experience of creating new national and sub-national formal strategies for sustainable development, focusing particularly on how policy communites operate. Because of our interest in the ways in which different strategies are expected to 'join up' with each other, we examined the interplay of how sustainable development strategies worked with those preparing sub-national spatial strategies, as these are all expected to make sustainable development a guiding theme. In undertaking this analysis we draw on 45 interviews with people involved in sustainable development debates, drawn from a range of sectoral backgrounds, about half of them from a planning background. The interviews were undertaken in 2005-6, and involved national lobby groups, government officials in various national ministries in Ireland and the UK, and in the devolved administrations.

\section{Sustainable Development Strategies at national and sub-national scales}

The UK Government, the Irish Government and the devolved administrations in Scotland, Wales and Northern Ireland have all issued sustainable 
development strategies indicating how they define sustainable development and their policy approach (Figure 1).

Figure 1 around here

\section{UK Sustainable Development Strategies and Framework}

The UK government has produced three national sustainable development strategies (DoE 1994; DETR 1999; and DEFRA 2005), each defining sustainable development and associated objectives and priorities in different ways. The first national sustainable development strategy reflected the wave of environmental concern that accompanied the period leading up to and following the 1992 Earth Summit in Rio de Janeiro (Owens and Cowell 2002). This strategy was far from being environment-led, and indeed was clear that it did not wish to impede economic development, but it did push government policy in the direction of greater environmental sensitivity than previously. The stronger environmental concern fed into various sectoral documents and practices, not least in planning.

The second strategy, A Better Quality of Life (DETR 1999), was produced by the new Labour government, and shifted the focus significantly, outlining four objectives which it suggested could and should be addressed simultaneously:

- social progress which recognises the needs of everyone;

○ effective protection of the environment;

- prudent use of natural resources; 
o maintenance of high and stable levels of economic growth and employment.

In pursuing this approach the strategy drew on a new vocabulary for promoting better policy integration: the removal of policy 'silos'; and the need to identify 'win-win-win' solutions where economic, social and environmental 'wins' could all be achieved rather than traded off against each other. In practice the UK government's definition for integrated sustainable development, though gaining widespread acceptance, proved difficult to interpret and to translate into other strategies.

The 2005 Sustainable Development Strategy, One Future - Different Paths (DEFRA 2005), explicitly acknowledges the problems which the government had come up against in achieving integration of all four sustainable development objectives, given that "different agencies focused on those one or two most relevant to them" (p.6). Arguing that it was developing rather than departing from the previous definition the strategy set out five new guiding principles (Figure 2).

Figures 2 and 3 around here

These principles are intended to apply UK-wide, forming part of a Strategic Framework for Sustainable Development (Figure 3). Critically however they were intended as a starting point for further policy elaboration, involving additional sustainable development strategies from the devolved 
administrations. A rationale for these changes is provided, namely that the new statement: "takes account of developments since 1999, both domestically and internationally: the changed structure of government in the UK with devolution to Scotland, Wales and Northern Ireland; greater emphasis on delivery at regional level and the new relationship between government and local authorities." (DEFRA 2005 p.13). England is in an anomalous position, lacking an overall 'national' strategy similar to those elsewhere, but with a network of regional frameworks (see below). This is perhaps one of the most clear-cut illustrations to date of an overt metagovernance mechanism being set in place that simultaneously brings actors together to agree a shared overarching framework, whilst allowing some further discretion for interpretation in the different devolved institutional settings.

The lead government department for sustainable development is now the Department for Environment, Food and Rural Affairs (DEFRA), but much play is made in the national strategy of a government-wide commitment to sustainable development. However, this has been pursued by government departments in an incoherent fashion, leading to confusion and frustration at the regional level (Sustainable Development Commission 2005 p.30).

These confusions also played out when it came to using sustainable development debates to shape policies. Our interviews revealed how some departments took it upon themselves to champion one or other of the four objectives or 'pillars,' in the process reinforcing longstanding differences between, for instance, those departments with an environmental remit such as 
DEFRA and those promoting national economic growth and competitiveness, such as the Department of Trade and Industry (DTI) and The Treasury. The joining-up was expected to occur elsewhere, but quite where was not always clear. As an example, one of our interviewees from one of the UK government's more 'economic' departments explained to us that whilst accepting the need for an integrated perspective of sustainable development, it was still quite appropriate for them to focus largely on one aspect:

I think we agree across government with the purpose of planning as expressed in PPS1... that sustainable development should be at the heart of the planning system... I think in practice we would focus on and champion the economic pillar... and where changes in planning policy are taking place we'll come to it with that perspective (Interview, UK government official: 10).

Whilst this interviewee felt that overall the approach worked and did deliver a 'balanced' approach, those outside central government tended to be less convinced.

\section{Wales Sustainable Development Scheme and Action Plan}

The devolution settlement in Wales is weaker than those in Scotland and Northern Ireland. The Welsh Assembly's legislative responsibilities are restricted to secondary and supplementary legislation limiting its ability to deliver sustainable development. Nevertheless, the Welsh Assembly is unique among the devolved governments in being required by law to prepare a 
scheme showing how it will promote sustainable development in exercising its functions (although see Greater London, below). The first scheme, Learning to Live Differently, was adopted in 2000, and a revised scheme was adopted in March 2004. The sustainable development scheme, together with the accompanying action plan, substitute for the sustainable development strategies of the other administrations. There are two other documents which support the Welsh approach to implementing sustainable development, the overall national strategy, Wales a better Country (2003) and the national spatial strategy, People, Places, Futures - the Wales Spatial Plan (2004).

The Welsh Assembly is required to revisit its sustainable development scheme every four years, after elections, and also to have an effectiveness report produced. The report on the effectiveness of the first Sustainable Development Scheme (CAG Consultants 2003) praised the Assembly for its efforts to mainstream sustainable development into its policies, but also noted that "There is little evidence that real change is happening on the ground" (ibid p.ix). Whilst the efforts of ministers and senior officers were praised for driving forward on sustainable development the Scheme itself was described as "Marginal to the Assembly's efforts to promote sustainable development, perhaps because it did not focus sufficiently on the crucial sustainable development issues facing Wales..." (p.xii). Building on the effectiveness report on the first scheme and consultation on a draft revision, a second scheme was issued in 2004, Starting to Live Differently. The same year, the Sustainable Development Action Plan was released, identifying priority actions for the period 2004-2007. 
Given the high profile of the Welsh Assembly's sustainable development activities, they have attracted a number of critiques already (see Flynn et al. 2003 Bishop and Flynn 2004, Williams and Thomas 2004, Mainwaring, Jones and Blackaby 2006). Particularly notable is a contribution to consultations on the Second Scheme from Friends of the Earth Wales (James 2004), which argued that the first years of activity had seen strong efforts at awareness raising, mainstreaming into different policy domains, and commitment at high levels within the Assembly. Despite such achievements however the report argued that sustainable development remained poorly understood by many individuals and organizations. Whether because of this poor understanding or for other reasons there have been issues when it come to implementation of developments on the ground. High profile decisions over leisure developments and controversy associated with introducing policy advice on renewable energy illustrate the complex politics of sustainable development. The Welsh Assembly's consultation on its renewable energy advice note exposed tensions within the environmental movement and within government itself about the benefits of onshore wind-farms in particular and their impact on high quality landscapes. The sustainable development scheme appears to have had limited influence when it comes down to the politics of these individual decisions.

There are some distinctive elements in the Welsh approach to sustainable development, including the breadth of issues which are seen to be part of the sustainable development agenda, and the strong link between the three main strategies, bringing together investment frameworks, spatial frameworks and a 
broad and integrative approach to sustainable development. There is also a strong commitment to working with overseas countries on sustainability issues. From our point of view, the distinctiveness of the Welsh approach is not so much in its thematic coverage of issues, but the way sustainable development is being deployed as part of an agenda for improving policy integration more broadly across the activities of the Assembly and those it works most closely with. This process is policed in many ways, the most high profile of which is the introduction of a 'policy integration tool'. This tool operates across all aspects of the Assembly's policy work, in effect performing a metagovernance role in seeking to ensure adherence to a centrally agreed set of criteria, including ones related to sustainable development. It is also quite striking how serioulsy engagement in transnational EU partnerships is taken by the Welsh Assembly, in contrast to say the English regions, where EU partnerships tend to be forged more at the local and sub-regional levels. The Welsh Assembly Government also makes strong play of its role in the European Sustainable Regions network (www.sustainable-euregions.net) and the Network of Regional Governments for Sustainable Development, which encourages networking, sharing of strategies and partnerships between members (see www.nrg4sd.net). In 2007 a £48m EU INTERREG programme was announced for improving links between Ireland and Wales, with sustainable development as one of its central themes. In essence the distinctive elements of the Welsh approach are its emphasis on the role of governmental purchasing (see Morgan, this special issue), policy integration and its associated scrutiny arrangements, and its extra-territorial networking. 


\section{Scotland's Sustainable Development Strategy}

The Scottish Parliament, with its greater devolved powers including primary legislation is perhaps in a stronger position to address sustainable development than Wales. The Scottish Executive set out its vision, priorities and indicators for sustainable development in Meeting the Needs... priorities actions and targets for sustainable development' (Scottish Executive 2002). Rather than set out a distinctive vision at that stage it sought to open up a debate based on the definition used by the World Commission on Environment and Development (1987). Whilst acknowledging that its priorities were for high economic growth and better quality of life, the executive indicated that this should not be achieved at the expense of the environment:

... the challenge of sustainable development is that these outcomes must be achieved whilst not requiring more than our fair share of the world's resources; and without giving rise to unacceptable discharges of pollutants (Scottish Executive 2002 para. 15).

More recently the Executive published Choosing our Future: Scotland's Sustainable Development Strategy (Scottish Executive 2005), which sought to build a distinctive Scottish approach. For example it emphasized environmental justice more strongly than other sub-national strategies, whilst also placing a major emphasis on health, welfare, food and nutrition.

There are evident tensions over the Scottish Executive's promotion of economic growth as a first order priority, including in planning where it is very much to the fore, albeit with sustainable development also presented as a key 
issue. Not surprisingly, this approach led to some critical comments in our interviews in Scotland, where the strong pursuit of economic development was recognized by all, but only recognized as a problem by some, mainly those not directly employed by the government. For some observers the emphasis on 'economic growth' was not simply driving sustainable development, but the form of growth being pursued was not much tempered by the environmental or social considerations which sustainable development is intended to capture:

I think this is another case of whether it does or does not do what it says on the tin. There is an awful lot of mantra to say that sustainable development is central to the Scottish Executive's policy yet when the chips are down economic growth has the highest priority... and it's not sustainable economic growth, it's just economic growth (Scotland, stakeholder interview: 2).

Whilst it could be argued that the strong economic emphasis within sustainable development reflects the distinctive needs of Scotland, in practice a similar set of arguments was encountered in London (see below), and to varying degrees in Wales, Northern Ireland, and many English regions. In Scotland itself there is some coherence in how sustainable development is being addressed across different strategies - but where in Wales the distinctive unifying theme concerned social issues, in Scotland the approach is most strongly focused around 'economic' matters. In content terms, the Scottish approach displays a strong commitment to health and poverty issues. 
This appears to be married to an enthusiasm to engage with practice elsewhere, not least with those working on sustainable development issues in others parts of the British Isles. As with Wales, levels of engagement with EU projects such as those funded under INTERREG, appear to attract considerable support from the Scottish Executive.

\section{Northern Ireland's Sustainable Development Strategy}

As devolution in Northern Ireland was suspended between 2002 and 2007, the first Sustainable Development Strategy for Northern Ireland, First Steps Towards Sustainability, was published by the UK Government's Northern Ireland Office (DOENI 2006). It is a large document, covering essentially the same thematic issues as those produced for Wales and Scotland, albeit with some presentational differences. Like them, great play is made of global environmental challenges as a starting point, in essence legitimating the need for a strategy and engendering a sense of urgency. There are calls for sustainable development to be addressed in a 'joined up' way, including across policy sectors and across the public, private, community and voluntary sectors. Taking its cue from the Welsh approach, a key tool for addressing such (metagovernance) issues is 'Integrated policy assessment', which is intended to allow departments and other public agencies to 'policy proof' all policies by combining Health Impact Assessment, Equality Impact Assessment, Rural Proofing, and Environmental Impact Assessment. 
First Steps is particularly strong in addressing social issues, not least fuel poverty, arguing that the social dimension of sustainability is essential given the high levels of deprivation which exist in Northern Ireland. Noting that the most disadvantaged lived in the most degraded environments, the document then highlights that in the context of Northern Ireland social and economic divides are overlain with the inheritance of "decades of sectarian conflict which divided communities at a time when they should be uniting to face the bigger challenges of the future" (ibid, 2006 p.68). Environmental justice issues in general emerge generally more strongly in the devolved territories relative to the UK national strategy and the strategies of the English regions.

Environmental governance also merits considerable attention, covering many of the issues found elsewhere, but overlain by a concern that

The contested nature of society in Northern Ireland has forged a culture that is not yet fully adapted to the new demands that sustainable development will place upon it in order to make the transition from global problems to inclusive local solutions. In some ways we have a steep learning curve compared with the rest of the UK or the Republic of Ireland, where sustainable development strategies have been in place since the late $90 \mathrm{~s}$. Where there is a challenge however there is also opportunity and we can and should learn from the lessons and experiences elsewhere" (p.123). 
This section is particularly interesting as an example of how sustainable development becomes embedded within existing discourses, in this case of rebuilding community relations at the local level and encouraging greater public engagement with the democratic apparatus. These are of course concerns found elsewhere, but in Northern Ireland there is an additional layer of meaning built into calls for greater public participation.

As in the other administrations, there was concern that whilst many departments paid lip-service to an integrated approach to sustainable development, in practice they continued to pursue their separate departmental interests:

[I]n government terms all departments are equal... no department has any priority over any other... and they all have their own programmes... they all have their own priorities... and sustainability is supposed to be right up there... and whilst this document [the Regional Development Strategy] is grounded in it, other strategies don't necessarily give sustainability that level of priority. So therefore they pay lip-service to it and they still carry on with their own programmes (Northern Ireland, stakeholder interview 6)".

Providing a helpful segue into the next section, the sustainable development strategy for Northern Ireland also notes that "We are acutely aware of the need to look at sustainability issues on All-Island basis" (Department of 
Environment Northern Ireland, p.8), noting on-going work to develop an allisland ecological footprint study and an all-island energy market framework.

\section{Ireland's Sustainable Development Strategy}

The sustainable development strategy for the Republic of Ireland (Department of the Environment 1997) reflects the political mood of when it was produced, adopting an approach focused on integrating environmental considerations into other policy sectors such as agriculture, forestry, industry and trade. The overall objective reflects the dominance of environmental issues within sustainable development debates at the time:

To ensure that economy and society in Ireland can develop to their full potential within a well protected environment, without compromising the quality of that environment, and with responsibility towards present and future generations and the wider international community (Department of the Environment 1997 p.25).

Subsequently the document 'Making Ireland's Development Sustainable' (Department of the Environment, Heritage and Local Government 2002) was produced for the Johannesburg World Summit on Sustainable Development in 2002. This in effect provides a new definition of sustainable development for the Irish government, reflecting an evolution in thinking, moving towards an emphasis on 'quality of life' and an integrative approach: 
Sustainable development is about getting the balance right between the economy, social issues and the environment so that we, as well as people in other parts of the world, are able to enjoy economic prosperity, social progress and a high quality of life - both now and in the future. It is about getting these 3 elements working together for a better quality of life, instead of gains in one area being offset by losses in another (ibid, p.3)

This integrative approach to sustainable development is reflected in the National Spatial Strategy (NSS) (Department of the Environment, Heritage and Local Government 2002), which makes much play of the need to address sustainable development concerns. There is a strong link too with the National Development Plan (NDP) for 2000-2006, which outlined the investment priorities of the government and called for the production of the NSS. The NDP referred to the need to reconcile economic growth with environmental concerns, but economic issues were nevertheless very much to the fore.

Irish regional policy is a relatively recent phenomenon, largely emerging out of different generations of compromise in order to ensure maximum access to European Structural Funds. A key driver in the regionalization of Irish governance was the need to prove to the European Commission some layer of regional partnership existed to guide allocation of regional funding. The strong environmental theme within European structural funding also exerted an influence on how national government and regional partners were forced to present their strategies. With a requirement to assess submitted strategies against the Commission's expectations on sustainability, this suggests the 
importance of the EU dimension to metagovernance, evidence in both Ireland and the UK. In the Irish case, the importance of the EU role is such that Mullally (2004 p.38) argues that:
It is perhaps incontrovertible to assert that the Irish response to regional sustainable development has been more concerned with Structural Funds than sustainable development.

Despite such well-founded skepticism about the initial motives of the government, sustainable development has become an increasingly important issue at regional level, as a component of Regional Planning Guidelines for instance. Whilst there is not a national coverage of regional sustainability strategies, as in England for instance (see below), local authorities in some regions have cooperated to prepare regional Local Agenda 21 statements.

There has also been a major study commissioned to look at progress towards sustainable development on an All-Island basis (Ellis et al. 2004). This argued that the existing institutional frameworks to promote sustainable development in the Republic of Ireland worked well and did not need changing, but a greater emphasis on implementation was needed. Northern Ireland however was felt to be lagging in its institutional fabric, lacking a national strategy at that time and without its own guidelines for Local Agenda 21 for instance. 


\section{Sustainable development frameworks in London and the English regions}

Because of the creation of the Greater London Authority (GLA) and the unique delegated powers of the London mayor for aspects of planning, economic development and transport, London has a greater capacity to address sustainable development than the other English regions. The Act setting up the GLA requires it to have regard to the effect of all its activities on the achievement of sustainable development in the UK. Given the degree of political devolution relative to other English regions our expectation was that the London approach would be fairly distinctive. In governance terms it is. The London Sustainable Development Commission is appointed by the Mayor and scrutinizes and formally publishes reports on various strategies. The Commission has strong representation from a variety of 'social' interests, which manifests itself in a commitment to diversity and equality objectives throughout its work. The Commission was responsible for producing the Regional Sustainable Development Framework (RSDF) for London, whose main distinctive feature is perhaps its length: just four pages, with the main content contained in just two pages. This is in stark contrast to the Northern Ireland strategy at 173 pages. In terms of content, whilst much of the London approach resembles that found elsewhere, it is very strong on issues around respect (covering diversity and community safety), and quite distinctive in tone in its commitment to 'fairness' in various forms, including an expectation of ethical business behaviour. 
It is at the level of sectoral strategies and individual policies where the stronger powers of London mean that distinctive and innovative policies have been developed, for instance in advice on urban design and the Congestion Charge. In each of these areas London has been able to take a fairly strong approach, even though sustainable development is just one of the justifications involved. It is perhaps worth noting that differences in political devolution and fiscal powers alone are not enough to set London apart: it is the combination of these with the capital's stronger economic position that gives local politicians and policy makers greater scope to pursue distinctive policies.

For the other English regions, plans to create elected regional assemblies were shelved after the referendum in the North East failed by a significant margin. In consequence responsibilities for sustainable development remain divided. Government Offices for the Regions established in 1994 to coordinate the activities of central government departments, exercise a policy overview, Regional Development Agencies are expected to contribute towards the achievement of sustainable development whilst unelected Regional Assemblies have led on the preparation of RSDFs. These strategies have been promoted by central government as a mechanism for promoting greater coherence and integration across different regional sectoral strategies. They are intended to provide a 'high level vision' and sustainable development objectives for each region, which should in turn inform all other regional strategies. To assist the process central government issued advice (DETR 2000) setting out what should be included in each RSDF. The guidance 
makes it clear that whilst regionally specific objectives could be developed that they must address the agreed national objectives for sustainable development. The result is that RSDFs had to reflect "regional distinctiveness or specific regional issues" (ibid, para 3.2.1), but conform to the broad national blueprint. Most English regions have now produced two rounds of frameworks (Figure 4).

Figure 4 around here

There appears to be a considerable uniformity in interpreting sustainable development in the English regions, with little sign of innovation emerging in broad strategic direction. This concern was picked up by a recent study of objectives in regional sustainable development frameworks in England (including London) (Regional Futures 2004):

The English regions have a very similar interpretation of 'sustainable development' in terms of economic, social and environmental objectives. This is not surprising given central guidance and the aspirations of people for quality of life (p.1)

In addition five English regions have now gone further than simply preparing regional frameworks for sustainable development, instead developing Integrated Regional Strategies (IRSs). Some regions also produced bespoke appraisal toolkits for those using the sustainability principles outlined in RSDFs or IRSs to appraise other plans and strategies. These include step-by- 
step guides to sustainability appraisal in the East Midlands and Yorkshire and Humber and the Integrated Appraisal Toolkit in the North West.

Despite such efforts, in a strongly-worded critique of progress on sustainable development in the English regions, the Sustainable Development Commission (SDC) argues that policies lacked coherence and regional ownership, in spite of the apparent progress in producing paper strategies:

UK Government guidance envisages that RSDFs should provide a shared vision and shared objectives for sustainable development in the region and inform other regional strategies. Our research, however, produced little evidence to suggest that RSDFs are either overarching or influential (Sustainable Development Commission 2006, p.33).

Nonetheless, when it comes to how sustainable development issues are subsequently translated into other strategies, we are seeing some variety. For instance, RDAs can differ widely in how they interpret the requirement to address sustainable development in their work, whilst claiming legitimacy through their conformity with the fairly bland RSDFs. In regional spatial strategies too, regional differences in interpretation of sustainable development concerns emerge despite broadly similar RSDFs (Counsell and Haughton 2003, Haughton and Counsell 2004). Lack of distinctiveness in regional sustainability frameworks then does not necessarily constrain regional distinctiveness in treatment of sustainability issues elsewhere within the governance system. 


\section{Overview: some structural and strategic dilemmas for sustainable development strategy work as metagovernance}

Two issues dominate this summary, to what extent did we see strategies for sustainable development display distinctiveness as a result of recent devolution initiatives in the UK and Ireland, and what do the results have to say about the structural contradictions and strategic challenges of metagovernance?

In broad terms it is possible to see how the UK government has engaged in a series of controlled experiments in devolution, with different forms of settlement in different territories. This is not a straightforward tactic of divide and rule - as the regional elections in North East England revealed, it also reflects in some part the very different aspirations and histories in different parts of the UK. In terms of sustainable development strategies, in its recent iterations the UK has moved to a much clearer hierarchy of national and subnational strategies. By first brokering agreement around a new national framework in 2005, the government was able to establish a broad agreement on sustainable development issues which necessarily framed subsequent strategies in Scotland, Northern Ireland and Wales. Politics also played a role

- Labour administrations were initially returned to power in Scotland and Wales, reducing the likelihood of major disagreements emerging with the national UK Labour government. In Northern Ireland, the power-sharing 
arrangements quickly broke down after devolution, with a return to administration from Whitehall, having a similar dampening effect on a search for policy distinctiveness. Our results perhaps reflect this political background - the emergence of new political administrations in Scotland, Wales and Northern Ireland in 2007 do, however, suggest greater changes may now be expected. Certainly the SNP-led Scottish Parliament appears to be committed to greening issues, making them one of its five overarching aims. It is still too early to judge whether this marks a move away from a strong prioritisation for economic growth, however.

In England, clear guidance notes on regional sustainable development frameworks provided an overarching context which it would be difficult for individual regions to break away from. London is an exception to this with its elected mayor, and it is the scrutiny role there that most stands out. With no progress now in prospect for regional political devolution in other English regions, it is not promising that the government proposes dismantling regional assemblies and giving greater powers to the RDAs, which are essentially economy-led. In this context, evidence of innovation in regional sustainable development work in the English regions is currently low and it is difficult to see this changing, with the exception perhaps of London. In Ireland, the national government has been less actively engaged in writing sustainable development strategies and in requiring these of sub-national authorities, creating a much more patchy coverage. Indeed, it is adherence to the formal requirements of EU structural funds which appear to have most shaped the Irish approach to sustainable development at sub-national level. 
Over time all the national and new territorial governments covered in this overview made explicit moves to adopt an integrated approach to sustainable development. This trend in part reflected the considerable degree of cooperation and consultation at each level of strategy production, involving the interchange of ideas from both bottom-up and top-down. Our work also suggests that a new pan-territorial policy network is emerging across the UK and Ireland, stretching beyond nation state boundaries, to debate what a national sustainable development strategy might consist of. At times this is less a network and more a series of loosely linked groupings engaged in identifying and developing new policy approaches within the broad sphere of sustainable development. This network is bolstered by links with areas outside the British Isles, especially with other EU regions. These evolving institutional mechanisms help explain how in practice a degree of similarity can be observed in the strategies of the devolved territories.

Charting how this process works proved difficult to unpick however. Changes in the tone and content of the different strategies appear to work through the system incrementally rather than in leaps or in response to central diktat, in part because there is so much intergovernmental cooperation and learning. Explicit examples can be found with the report on All-Island Sustainable Development (Ellis et al. 2004), in the introduction to the Northern Ireland strategy which reviews other territorial sustainability strategies, and also the Scottish Parliament briefing paper on sustainable development which reviews progress elsewhere to inform Scottish politicians (Crook 2003). Another 
example of this sharing of experience is cited in the UK government's response (DEFRA 2006) to the Sustainable Development Commission report on sustainable development in the regions (see above), which points to the considerable amount of joint working and learning going on within and across the English regions. Our interviews additionally revealed the considerable importance for some key actors of participation in various EU sustainability and spatial planning initiatives in building a common knowledge base. This is particularly evident in Wales, which has been active in building EU networks for sharing experience (Flynn et al. 2003).

Supporting this intergovernmental and international sharing of knowledge is the insertion of new approaches to 'auditing' or 'scrutinising' progress towards sustainable development, which can work variously to challenge or reinforce conventional thinking about sustainable development. Examples might include for instance the distinctive flavour which the London Sustainable Development Commission brings to its reviews of various GLA strategies, the All-Island report on sustainable development (see above), the role of the UK's national Sustainable Development Commission in producing critical reports, and the growing use of integrated policy assessment and sustainability appraisal.

This article has started to identify some of the metagovernance issues associated with producing sustainable development strategies in the context of stronger devolution, including a series of structural and strategic dilemmas which continue to shape its possibilities. We can identify some greater distinctiveness emerging, but in truth it is early days yet for the devolution 
project and it will be some years yet before the true potential for regionally distinctive approaches will be fulfilled, if it ever is. This caveat is added because as we pointed out earlier, national governments seeking to unleash the potential of devolution are also necessarily wary of letting go the strings of power and possibly undermining the national project for economic growth.

In this respect it is worth remembering that sustainable development strategies are just one part of how processes of metagovernance work, with many of them difficult to identify and analyse. With widespread consultation common, sustainable development strategy preparations are relatively transparent and wide-ranging in how they work and therefore yield useful insights to the tensions involved in resolving some of the strategic dilemmas and structural contradictions we noted earlier. Framing analysis of sustainable development strategy work in the context of metagovernance helps reveal two things. First, the imposition of clear frameworks within which territorial administrations must prepare their own strategic documents, and second the way in which various interlocking networks emerge, with varying geographies and memberships, which serve to broker consensus and share innovative practices. Metagovernance then is a sometimes subtle and still little understood process. Through administrative routines, practices and norms it smooths difference as it works through both hierarchical and networked forms of governance. It reinforces path dependencies as it brokers formal rules and less formal understandings of what is politically, administratively and scientifically accurate, acceptable and appropriate. In the case of preparing sustainable development strategies it appears to have involved the 
construction of a new policy network and the creation of new spaces of governance, through which these shared understandings could emerge.

\section{References}

Allmendinger P and Haughton G (2007) The fluid scales and scope of UK spatial planning, Environment and Planning A, 39(6), 1478-1496.

Benneworth P, Conroy L, and Roberts P(2002) Strategic connectivity, sustainable development and the new English regional governance Journal of Environmental Planning and Management, 44.2, 199-217.

Bishop, K. and Flynn, A. (2004) Sustainable Development in Wales: schemes and structures, debates and delivery. Contemporary Wales, 17 92-112.

Cabinet Office (1999a) Modernising Government. London, The Stationery Office

Cabinet Office (1999b) Professional policy making for the twenty-first century London, The Stationery Office.

CAG Consultants (2003) How efficiently has the National Assembly for Wales promoted sustainable development? Report to the Welsh Assembly Government. London, CAG.

Coleman, W.D., Skogstad, G.D., and Atkinson, M.M, 1997, Paradigm shifts and policy networks: cumulative change in agriculture, Journal of Public Policy, 16 (3), pp.273-301.

Cook, G. (2003) Sustainable Development SPICe briefing. Edinburgh, The Scottish Parliament. 
Cooke P and Clifton N (2005) Visionary, precautionary and constrained 'varieties of devolution in the economic governance of the devolved UK territories' Regional Studies 39.4, 437-451.

Counsell, D. and Haughton, G.F. (2003) Regional Planning in Transition: planning for growth and sustainable development in two contrasting regions. Environment and Planning C, 21 225-239.

DEFRA (2005) Securing the Future: UK Government Sustainable Development Strategy. London, The Stationery Office

DEFRA (2006) Securing the Regions' Futures. London, DEFRA Publications.

DETR (1999) A Better Quality of Life - Strategy for Sustainable Development for the UK. London, The Stationery Office

DETR (2000) 'Guidance on preparing Regional Sustainable Development Frameworks', DETR, London.

Department of Environment (DoE) (1994) Sustainable Development: the UK Strategy. London, HMSO

Department of the Environment (1997) Sustainable development: a strategy for Ireland, Government Publications, Dublin.

Department of the Environment, Heritage and Local Government (2002) National Spatial Strategy. DOHLG, Dublin

Department of the Environment, Heritage and Local Government (2002) Making Ireland's Development Sustainable: review, assessment and future actions' DEHLG, Dublin.

Department of Environment Northern Ireland (DOENI) (2006) First Steps Towards Sustainability, Belfast, DOENI. Accessed August 2006: http://www.doeni.gov.uk/epd/susdev.pdf 
Ellis, G., Motherway, B.. Neill, W.J.V., Hand, U. (2004) Towards a Green Ireland. Armagh, Centre for Cross Border Studies

Flynn A, Netherwood A, and Bishop K (2003) 'Multilevel governance and sustainable development in Wales' in Lafferty W.M. and Narodoslawsky M (eds) Regional Sustainable Development in Europe: the challenge of multi-level cooperative governance, Oslo, ProSus, pp.68-89.

Goodwin, M, Jones M and Jones R (2005) 'Devolution, constitutional change and economic development: explaining and understanding the new institutional geographies of the British state' Regional Studies, 39.4, 421436.

Gunder M (2006) ‘Sustainability. Planning’s saving grace or road to perdition? Journal of Planning Education and Research, 26, 208-221.

Haughton G and Counsell D (2004) Regions, Spatial Strategies and Sustainable Development, Routledge, London.

James, G. (2004) Sustaining Spin: an assessment of the mainstreaming of sustainable development by the Welsh Assembly Government and local authorities in Wales. Friends of the Earth Wales.

Jessop, B (2000) The Crisis of the National Spatio-Temporal Fix and the Ecological Dominance of Globalizing. International Journal of Urban and Regional Research, 24 (2), 323-360.

Jessop, B. (2003) 'Governance and meta-governance. On Reflexivity, Requisite Variety, and Requisite Irony', in H. Bang, ed., Governance, Governmentality and Democracy, Manchester: Manchester University Press. 
Jessop, B (2004) Multi-level Governance and Multi-level Metagovernance Changes in the European Union as Integral Moments in the Transformation and Reorientation of Contemporary Statehood. In: Bache, I. and Flinders, M. (eds) Multi-Level Governance. Oxford University Press, Oxford, UK.

Keating M (2005) Policy convergence and divergence in Scotland under devolution, Regional Studies 39.4 453-463.

Lafferty W. M. and Eckerberg K (eds) 1998) From the Earth Summit to Local Agenda 21, London, Earthscan.

Lafferty W.M. and Narodoslawsky M (eds) (2003) Regional Sustainable Development in Europe: the challenge of multi-level cooperative governance, Oslo, ProSus.

MacKinnon,D., and Vigar G. (forthcoming) Devolution and the changing policy spaces of UK transport planning, in Doherty,I., and Shaw, J., (eds.) Traffic Jam, Policy Press, Bristol.

Mainwaring, L.; Jones, R. and Blackaby, D. (2006) Devolution, sustainability and GDP convergence: is the Welsh agenda achievable? Regional Studies, 40(6) 679-689

Marsh, D., and Rhodes, R., (eds.) (1992) Policy Networks in British Government, Oxford: Oxford University Press

Mayor of London (2004) The London Plan. Greater London Assembly, London. Morgan K (2001) The new territorial politics: rivalry and justice in postdevolution Britain Regional Studies 35 343-348.

Morgan K (2002) 'The English question: regional perspectives on a fractured nation' Regional Studies, 36.7, 797-810. 
Mullally, G. (2004) Shakespeare, the Structural Funds and Sustainable Development: reflections on the Irish experience. Innovation, 17 (1) 2541

Owens, S. and Cowell, R. (2002) Land and Limits: interpreting sustainability in the planning process. Routledge, London.

Performance and Innovation Unit (2000) Wiring it up: Whitehall's management of cross-cutting policies and services. London, The Stationery Office.

Regional Futures (2004) A comparison of regional sustainable development objectives. Cheltenham, Forum for the Future.

Scottish Executive (2002) Meeting the Needs... priorities actions and targets for sustainable development. Edinburgh, Scottish Executive.

Scottish Executive (2005) Choosing our future: Scotland's Sustainable Development Strategy. Edinburgh, Scottish Executive.

Smith, M., 1993, Pressure Power and Policy: state autonomy and policy networks in Britain and the United States, Hemel Hempstead: Harvester Wheatsheaf.

Sustainable Development Commission (2005) The Next Steps: an independent review of sustainable development in the English regions. London, SDC.

Vigar, G., Healey, P., Hull, A. and Davoudi, S. (2000) Planning, Governance and Spatial Strategy in Britain. Basingstoke, Macmillan.

Welsh Assembly Government (2000) Starting to Live Differently: the Sustainable Development Scheme of the National Assembly for Wales. Cardiff, WAG 
Welsh Assembly Government (2004) Starting to Live Differently: the Sustainable Development Scheme of the National Assembly for Wales. Cardiff, WAG.

Welsh Assembly Government (2004) The Sustainable Development Action Plan 2004-2007. Cardiff, WAG.

Welsh Assembly Government (2004) People, Places, Futures: The Wales Spatial Plan. Cardiff, WAG.

Whitehead, M (2003) 'In the shadow of hierarchy' : Meta-governance, policy reform and urban regeneration in the West Midlands. Area 35(1), pp 6-14. Williams, P. and Thomas, A. (2004) Sustainable Development in Wales: understanding effective governance. York, Joseph Rowntree Foundation

World Commission on Environment and Development (1987) Our Common Future, Oxford University Press, Oxford. 


\begin{tabular}{|c|c|}
\hline Sustainable development strategy & Date(s) of publication \\
\hline \multicolumn{2}{|l|}{ UK-wide } \\
\hline Sustainable development: the UK Strategy & 1994 \\
\hline $\begin{array}{l}\text { A Better Quality of Life: Strategy for Sustainable } \\
\text { Development for the UK }\end{array}$ & 1999 \\
\hline $\begin{array}{l}\text { Securing the future: UK Government Sustainable } \\
\text { Development Strategy }\end{array}$ & 2005 \\
\hline \multicolumn{2}{|l|}{ Northern Ireland } \\
\hline First Steps Towards Sustainability & 2006 \\
\hline \multicolumn{2}{|l|}{ Scotland } \\
\hline $\begin{array}{l}\text { Meeting the Needs... priorities actions and targets } \\
\text { for sustainable development }\end{array}$ & 2002 \\
\hline $\begin{array}{l}\text { Choosing our future: Scotland's Sustainable } \\
\text { Development Strategy }\end{array}$ & 2005 \\
\hline \multicolumn{2}{|l|}{ Wales } \\
\hline $\begin{array}{l}\text { Learning to live differently: the Sustainable } \\
\text { Development Scheme of the National Assembly for } \\
\text { Wales }\end{array}$ & 2000 \\
\hline $\begin{array}{l}\text { Starting to live differently: the Sustainable } \\
\text { Development Scheme of the National Assembly for } \\
\text { Wales }\end{array}$ & 2004 \\
\hline $\begin{array}{l}\text { The Sustainable Development Action Plan 2004- } \\
2007\end{array}$ & 2004 \\
\hline \multicolumn{2}{|l|}{ Republic of Ireland } \\
\hline Sustainable development: a Strategy for Ireland & 1997 \\
\hline Making Ireland's Development Sustainable & 2002 \\
\hline
\end{tabular}

Figure 1: National sustainable development strategies and frameworks in the UK and Ireland 


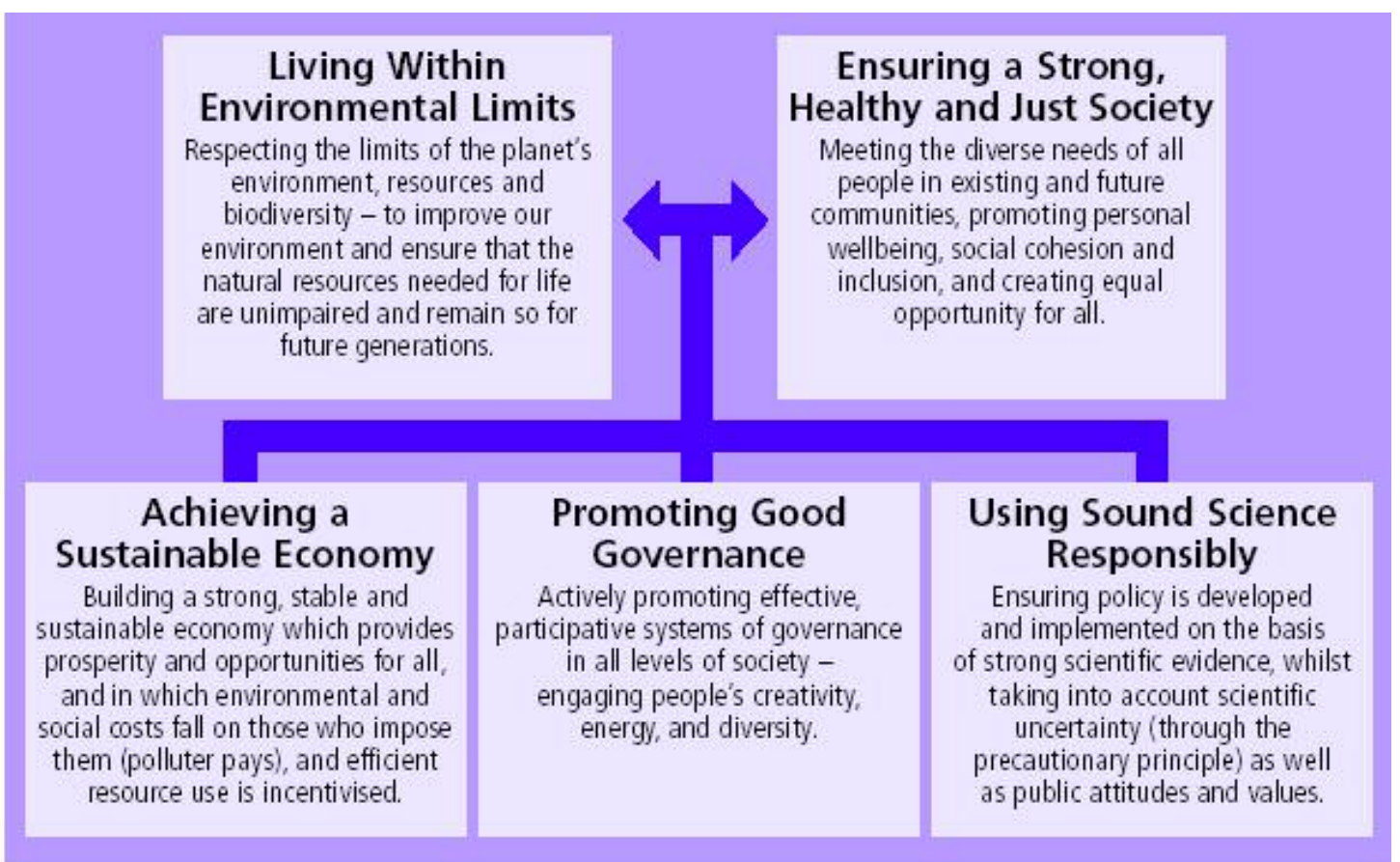

Figure 2: Key principles (DEFRA, 2005, p.7)

Figure 3: UK Strategic Framework (DEFRA 2005a)

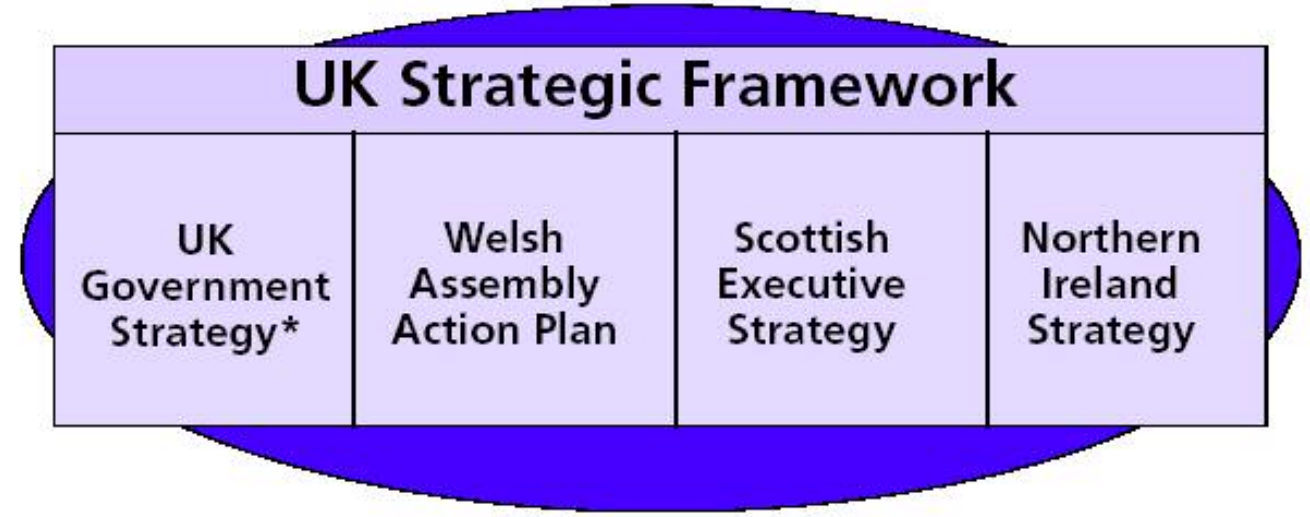

*Covers Enqland and all non-devolved issues, including international relations 


\begin{tabular}{|c|c|}
\hline Sustainable development framework & Publication dates \\
\hline \multicolumn{2}{|l|}{$\begin{array}{ll}2 & \text { London }\end{array}$} \\
\hline A Sustainable Development Framework for London & 2003 \\
\hline \multicolumn{2}{|l|}{ English Regions: North East } \\
\hline $\begin{array}{l}\text { Quality of Life in the North East: towards a regional } \\
\text { framework }\end{array}$ & 2002 \\
\hline $\begin{array}{l}\text { Achieving a better quality of life: The Integrated } \\
\text { Regional Framework for the North East }\end{array}$ & 2004 \\
\hline \multicolumn{2}{|l|}{ North West } \\
\hline $\begin{array}{l}\text { Action for Sustainability: the Regional Sustainable } \\
\text { Development Framework for the North West }\end{array}$ & 2000 \\
\hline $\begin{array}{l}\text { Action for Sustainability: the Regional Sustainable } \\
\text { Development Framework for the North West (revised) }\end{array}$ & 2004 \\
\hline \multicolumn{2}{|l|}{ Yorkshire and Humber } \\
\hline $\begin{array}{l}\text { Advancing Together: towards a sustainable region. } \\
\text { The Regional Sustainable Development Framework } \\
\text { for Yorkshire and Humberside }\end{array}$ & 2001 \\
\hline $\begin{array}{l}\text { Building the benefits: Yorkshire and Humber Regional } \\
\text { Sustainable Development Framework Update - 2003- } \\
2005\end{array}$ & 2003 \\
\hline \multicolumn{2}{|l|}{ East Midlands } \\
\hline $\begin{array}{l}\text { England's East Midlands Integrated Regional Strategy: } \\
\text { Our Sustainable Development Framework }\end{array}$ & 2000 \\
\hline $\begin{array}{l}\text { England's East Midlands Integrated Regional Strategy: } \\
\text { Our Sustainable Development Framework }\end{array}$ & 2005 \\
\hline \multicolumn{2}{|l|}{ West Midlands } \\
\hline $\begin{array}{l}\text { Quality of Life: the future starts here - A Sustainability } \\
\text { Strategy for the West Midlands }\end{array}$ & 2000 \\
\hline $\begin{array}{l}\text { A sustainable future for the West Midlands: A Regional } \\
\text { Sustainable Development Framework - version } 1\end{array}$ & 2005 \\
\hline \multicolumn{2}{|l|}{ East of England } \\
\hline $\begin{array}{l}\text { A Sustainable Development Framework for the East of } \\
\text { England }\end{array}$ & 2001 \\
\hline $\begin{array}{l}\text { Sustainable Futures: The Integrated Regional Strategy } \\
\text { for the East of England }\end{array}$ & 2005 \\
\hline \multicolumn{2}{|l|}{ South East } \\
\hline A better quality of life in the South East & 2001 \\
\hline $\begin{array}{l}\text { A better quality of life for the South East: Integrated } \\
\text { Regional Framework } 2004\end{array}$ & 2004 \\
\hline \multicolumn{2}{|l|}{ South West } \\
\hline A Sustainable Future for the South West & 2000 \\
\hline $\begin{array}{l}\text { Just connect: An Integrated Regional Strategy for the } \\
\text { South West 2004-2026 }\end{array}$ & 2004 \\
\hline
\end{tabular}

Figure 4: Sustainable development frameworks - London and the English regions 